\title{
Regional AdVANtage
}



Regional Advantage

CULTURE AND COMPETITION IN Silicon VAlLey and ROUte 128

ANNALEE SAXENIAN

HARVARD UNIVERSITY PRESS 


\section{TO JAMIE, WHO SET THE DEADLINE}

\section{AND tO MARTY, WHO HELPED ME MEET IT}

Copyright (C) 1994, 1996 by the President and Fellows of Harvard College

All rights reserved

Printed in the United States of America

First Harvard University Press paperback edition, 1996

Library of Congress Cataloging-in-Publication Data

Saxenian, AnnaLee.

Regional advantage : culture and competition in Silicon Valley and Route 128 / AnnaLee Saxenian.

p. $\mathrm{cm}$.

Includes bibliographical references and index.

ISBN 0-674-75339-9 (alk. paper)

ISBN 0-674-75340-2 (pbk.)

1. High technology industries-California, Northern.

2. High technology industries-Massachusetts.

3. United States-Economic conditions-1981-

-Regional disparities.

I. Title.

HC107.C22N677 1994

$338.4^{\prime} 762^{\prime} 000979473-\mathrm{dc} 20$

$93-39416$

Designed by Gwen Frankfeldt 